\title{
Would marketing capability and network resource influ- ence business performance? The case of Bumiputera on- line entrepreneurs in Malaysia
}

\author{
Dewi Izzwi, A. M. ${ }^{1 *}$, Zila, Z. A ${ }^{2}$, Zaidatulnisha, A. J. ${ }^{3}$, Fazrul Radzi, S. ${ }^{4}$ \\ 1, 2, 3,4 School of Business and Accountancy, Kolej Universiti Poly Tech Mara, Kuala Lumpur, Malaysia
}

\section{Keywords \\ Online entrepreneurs \\ Performance \\ Marketing capability \\ Network resource \\ Bumiputera}

Received: 12 June 2018

Accepted: 17 July 2018

Published: 2 August 2018

\begin{abstract}
The rapid development of information communication technologies has created business opportunities for individuals to create wealth, where these individuals may or may not be employed by organizations. Online business has gained popularity as it allows individuals to generate income at their convenience, regardless of their age, marital status, or ethnicity. Nevertheless, not all individuals are successful with their online businesses. The performance differences were found among Bumiputera online entrepreneurs, which then raised the question of what factors contributed to such differences. Using resource-based view as the underpinning theory, this research argued that marketing capability and network resources would contribute to their business performance. Hence, this research was conducted to determine the relationship between marketing capability, network resources, and performance of Bumiputera online entrepreneurs. Using face-to-face and online surveys, 158 responses were collected from Bumiputera online entrepreneurs throughout Malaysia. Results from regression analysis found that both marketing and network directly correlated with most of the performance indicators. However, the influence of the network as the moderator was not significant and needed to be further explored. The research findings can be useful to online entrepreneurs and contribute to the content development of entrepreneurship programs. It is recommended to strengthen measurements for marketing capability and network resources of online entrepreneurs for future research.
\end{abstract}

(C) 2018 The Author(s). Published by TAF Publishing.

\section{INTRODUCTION}

The internet and the development of information communication technologies have given rise to online shopping behaviors among people around the world. In Malaysia, it was reported by Malaysia Digital Economy Corporation (MDEC) that Malaysia consumers were highlighted as the top (67\%) online shopaholic in the Asian countries, in which 7 percent online shoppers made daily online purchase, followed by 26 percent made a purchase once a week, followed by 54 percent on monthly basis and 13 percent on a yearly basis (Ee, 2017). The online shopping behavior among consumers thus has created a new business model and restructured the distribution channels, where online stores are developed to cater the needs of online shoppers.
In Malaysia, the trend of online shopping has opened up opportunities for individuals to create wealth by becoming online entrepreneurs. In addition, the government put lots of effort in strengthening the internet infrastructure and usage, and offering various entrepreneurship programs to support entrepreneurs (AT Kearney, n.d). Furthermore, the benefits received from doing the business online are plentiful as it enables sellers to save cost, advertise their products and services, obtain information timely and consistently, be efficient in the use of time in terms of ordering and payment, develops strong customer service and relationships, tailors products to customers' specifications, achieves advantages over competitors, and run their business at their own convenience (Krisnawati, Perangin-Angin, Zainal, \& Suardi, 2016; Kuo \& Chen, 2015; Wen, Chen, \& Hwang, 2001). With

* corresponding author: Dewi Izzwi, A. M.

†email: dewi@gapps.kptm.edu.my 
the government's contribution and the collective benefits this may contribute to the rise in the number of online entrepreneurs in Malaysia. Based on Companies Commission of Malaysia (SSM) data as at May 2017, with an average 1,000 per month, there were 50,882 online entrepreneurs that had registered their online business (Bernama, 2017). The large number of online entrepreneurs indicates that the competition among these online entrepreneurs may be quite intense. As these online entrepreneurs need to fight for the attention of online consumers, they must develop and enhance their marketing capability to ensure the products or services offered are demanded, reasonably priced, attractively promoted, and fast and conveniently delivered. However, network resource is also important for online entrepreneurs. Since online entrepreneurs may work at their convenience-own place, own time-they will be physically isolated from other people (Adora, 2017; Bizon, 2016; Di Domenico, Daniel, \& Nunan, 2014). Hence, they need to build connections with family, friends, neighbour, customers and even other online entrepreneurs in order to get emotional and physical assistance.

Based on the discussion above, it can be seen that both marketing capability and network resource are important factors that could help online entrepreneurs to succeed. However, the studies that investigate these factors as performance determinants of online entrepreneurs in Malaysia are still lacking. And it is more difficult to find a study that focuses on the Bumiputera entrepreneurs. To get an overview of their performance an exploratory study was conducted where interviews with 20 Bumiputera online entrepreneurs was done. Findings of the interview discovered that while there were entrepreneurs who satisfied with their achievements, others felt disappointed due to various obstacles and problems. This is quite worrisome because as in 2017, Bumiputera was estimated to be $68.6 \%$ of the Malaysian total population by the Department of Statistics (Department of Statistics, 2017).

Creating wealth and correcting economic disparity among communities especially the Bumiputera have been Malaysia's agenda since the institution of New Economic Policy (NEP) in 1970 (Ishak, 2014). Therefore, this study was conducted to confirm whether marketing capability and network resource contribute towards the performance satisfaction of Bumiputera online entrepreneurs in Malaysia. There were three objectives of this study including:

1. To determine the relationship between marketing capability and performance of Bumiputera online entrepreneurs.
2. To identify the relationship between network resource and performance of Bumiputera online entrepreneurs.

3 . To test the moderating role of network resource on marketing capability-performance of Bumiputera online entrepreneurs relationship.

The research findings are significant as they provide some advices to the practitioners-the Bumiputera online entrepreneurs-on which important resource and capability needed to strengthen their business performance. Institutions that involve in entrepreneurship development programs may also get some input for their curriculum content.

\section{LITERATURE REVIEW}

\section{Marketing and Marketing Capability}

In general, marketing activities are discussed in the areas of products and services conception and offering, price setting, products and services promotion, and products and services deliveries (Eze, 2017; Kali, 1999; Oetomo \& Budiyanto, 2017).

So how do online entrepreneurs carry out their marketing activities?

Product: In doing online business, the entrepreneurs must select the right products and services. According to Irfan (2013), the choice of product depends on a person's interest or market demand, and therefore, online entrepreneurs can sell anything that he or she wants. Hence, the products being offered can be new products or pre-loved products; can be hand-made or created by other people or businesses.

Price: Technology makes the entry into online business easier that resulted to higher level of competition (Porter \& ilustraciones Gibbs, 2001; Shin \& Seo, 2017). Hence, online entrepreneurs must be very careful in setting the price for their products. In his book, Irfan (2013) wrote that for new online entrepreneurs, lower price may be preferable as this would encourage customers to make repeat purchases. Nevertheless, he clarifies that the price set should match with the true value of products sold because benefits and values are the real buying decision criteria.

Promotion: Since online entrepreneurs conduct their business virtually, their promotions are done using phones, website and social media such as Instagram, Blog and Facebook. The choice of advertising tools must be able to capture customers' interest and influence them to purchase the products and services being offered. According to Miliza (2016), pictures are very essential for online business because products' pictures attract customer's attention and aid them to make decision to buy. In addition, there are also online entrepreneurs who utilize the dropship system. The system uses agents to connect between buyers and sell- 
ers by helping online entrepreneurs to promote and accept orders (Anggadwita, 2016; Nor Liza, 2016).

Place: One of the main distinctions between brick-andmortar and online entrepreneur is the way products are being delivered (Ripain, Amirul, \& Mail, 2017; Vertel, 2012). Since online entrepreneurs work from any convenient places such as their own home (Di Domenico et al., 2014), the products reached the customers by hand or through postal and delivery services (Miliza, 2016).

In performing these marketing activities, online entrepreneurs are said to have marketing capability. Marketing capability reflect the ability to deploy collective resources including knowledge, skills and other available resources to satisfy market needs and wants, better than competitors (Chang, 1996; Krasnikov \& Jayachandran, 2008; Tsai \& Shih, 2004; Vorhies, Harker, \& Rao, 1999; Weerawardena, 2003).

How important is marketing capability? From resourcebased view theory, marketing capability allows market needs to be met; and for that reason, marketing capability is considered as valuable (Srivastava, Fahey, \& Christensen, 2001). The capability is rare because it cannot be procured and needs to be nurtured by the firms themselves (Krasnikov \& Jayachandran, 2008). The capability is not easy to be exactly replicated because its development is based on accumulated and integrated knowledge, skills, and resources (Alshehhi, 2016; Vorhies et al., 1999), lessons learnt over a period of time (Srivastava et al., 2001), and interactions with people, physical and management competences (Möller \& Anttila, 1987). All of these elements reflect causal ambiguity, time compression diseconomies and path dependency, which prevent opponents from imitating the same capability (Dierickx \& Cool, 1989). Last but not least, marketing capability can be considered as nonsubstitutable because it relies on the knowledge, ability and experience of a person (Wright, McMahan, \& McWilliams, 1994).

Would marketing capability affect business performance? According to the resource-based view theory, resources and capabilities that have the four strategic traits-valuable, rare, inimitable and non-substitutable-would result sustainable competitive advantage and thus affect long term performance of a business (J. Barney, 1991; Day, 1994; Rouse \& Daellenbach, 1999). Hence, various studies in the past have found the significance influence of marketing capability on business performance e.g., (Azizi, Movahed, \& Khah, 2009; Krasnikov \& Jayachandran, 2008; Vorhies et al., 1999). Based on the above review the first hypothesis for this research is:
H1: The stronger the marketing capability, the higher the performance of Bumiputera online entrepreneurs

\section{Network Resources}

Network resource is the direct and indirect connections or ties that are built with other firms, groups or individuals for social or economic purposes (O'Donnell, Gilmore, Cummins, \& Carson, 2001). These individuals may be the suppliers, customers, or other competitors (Gulati, Nohria, \& Zaheer, 2000).

How important is network resource? From the perspective of resource-based view theory, network resource is an intangible resource that is valuable, rare, inimitable and non-substitutable. Both weak and strong ties are beneficial to entrepreneurs as it could lead to success (Eyal, 2008). Weak ties are important because they provide values of non-redundant information, which in turn ensure the acquisition of different kind of information from the connections (Granovetter, 1983). Burt (2000) added that strong ties are equally important because they created strong trust among members within the network, and this would ensure that the information passed through the network is reliable and timely. Besides information, network also allows the network members the opportunity to gain resources, technologies, and markets (Gulati et al., 2000). Hence, through network, online entrepreneurs may be able to get the right and timely information, and access to other resource that could aid them to make use of the available opportunities and/or defuse unfavorable pressures (Foss et al., 1999).

Network is considered as rare because it cannot be bought in the open market but need to be built by own selves, which make the network combination unique (Foss et al., 1999). Furthermore, the opportunity to work together is not available to everybody equally (Ahuja, 2000).

Network is not easy to be imitated because it involves special social relationships with many individuals and firms, which are created based on trust over a lengthy period of time (Ainuddin, Beamish, Hulland, \& Rouse, 2007; Foss et al., 1999; Kali, 1999; Smith \& Lohrke, 2008). Network is also difficult to be replaced. The support, information and other resources available to one network are unique, and thus different from other networks (Gulati et al., 2000). Even if somebody is able to duplicate the same network, the time taken for the process is a long one (Foss et al., 1999). Therefore, it is argued here that network resource is equally important to online entrepreneurs. Because they are physically isolated from other people, online entrepreneurs need to connect and communicate with customers (Azlina, 2016; Di Domenico et al., 2014). Both informal and formal net- 
work would help online entrepreneurs to get the right and timely information, advices, and other resources such as financial, tools and machines, and even goods and services. Since online entrepreneurship work with the aid of the internet, communication technologies, and social media, online networking is very much play big role in their business operation. Online entrepreneurs thus are advisable to utilize the web-based social networking in a way that is reliable with their marketing strategy (Paquette, 2013). Anwar and Daniel (2016) also stressed on the relevancy of network to online entrepreneurs, where they said web-based networking could aid online entrepreneurs to be dynamic and flexible enough to be close to clients, and at the same time deal with constrained assets.

Would network resource contribute to business performance? Since network resource is valuable, rare, inimitable and non-substitutable, J. Barney (1991), J. B. Barney (1995) said yes, the resource could influence performance. This is supported by many studies in the past that found positive relationship between network resource and business and entrepreneurship performance e.g., (Ainuddin et al., 2007; Chen, Tzeng, Ou, \& Chang, 2007; Jones \& Jayawarna, 2010; Lechner \& Dowling, 2003; Madsen, 2007).

Nevertheless, it is important to note that network resource could also moderate a certain relationship. For example, Yang and Lin (2012) found that network resource strengthen the effect of network dynamic and performance. Based on this, it is argued that network resource could also strengthen the effect of marketing capability and performance of online entrepreneurs. But, Vissa and Chacar (2006) found that while network influence the performance directly, there is no significance contribution of networks as the moderator. Based on the foregoing review, the next hypotheses for this research are:

H2: The stronger the network resource, the higher the performance of Bumiputera online entrepreneurs

H3: Network resource moderates the relationship between marketing capability and the performance of Bumiputera online entrepreneurs.

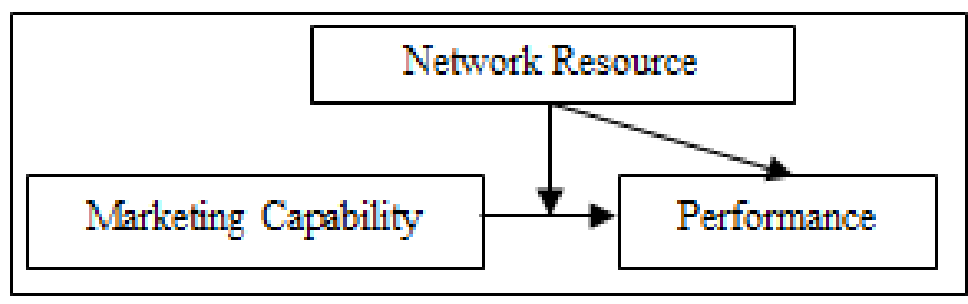

FIGURE 1. Research model

The relationship of the variables can be illustrated through the framework shown in Figure 1.

\section{METHODOLOGY}

The measurement for marketing capability was adapted from Weerawardena (2003). After the face validation and pilot test, the measurement was adjusted. As a result, marketing capability was measured by six items, where the respondents were asked about their capability in terms of product, price, promotion and distribution. The reliability for marketing capability measurement was 0.803 . Factor analysis showed that KMO was 0.810 , and each item loading was more than 0.5 . Furthermore, only one component resulted from the analysis indicating that all items were measuring marketing capability.

The measurement for network resource was adapted from Borch, Huse, and Senneseth (1999). After the face validation and pilot test, the measurement was adjusted. At the end, network resource was measured by six items where the Bumiputera online entrepreneurs were asked whether their networks enable them to have trusted friends, business opportunities, information, help when needed, timely information, and resources that they do not have. The reliability for network resource was 0.841 . Factor analysis showed that KMO was 0.841 , and each item loading was more than 0.6. In addition, only one component resulted from the analysis, indicating that that all items were measuring network resource.

Performance was measured subjectively. This was the online Bumiputera entrepreneurs' performance satisfaction towards profit growth, sales growth, number of new customers growth, and number of repeat customer growth. Performance satisfaction was used because it ensured respondents' willingness to respond, and it reflected online entrepreneurs' personal aim. Factor analysis revealed that all of the items can be treated unidimension-named overall performance growth-where the KMO was 0.728 with item loadings more than 0.7 . The reliability for overall performance was 0.797 . 
A total of 158 Bumiputera online entrepreneurs responded to the actual survey. The survey was done in the form of questionnaire, which was distributed randomly through online survey and by-hand. Data were analyzed using descriptive statistics, factor analysis and multiple regression analysis.

\section{ANALYSIS AND FINDINGS \\ Respondents Profile}

The oldest respondent was 53 years old while the youngest was 14 years old. In term of gender, $81 \%$ respondents were female and the rest $19 \%$ were male. $46 \%$ respondents said they chose to do online business on a full time bases while another $54 \%$ did their online business part-timely. In term of formal education achievement, 58\% respondents had bachelor, master and doctorate degree while the rest $42 \%$ had diploma, certificate and completed only up to school levels.

\section{Marketing Capability, Network Resource and Profit Growth}

Table 1 shows the result for the contribution of marketing capability and network resource towards profit growth satisfaction of Bumiputera online entrepreneurs. When there was no moderator, both marketing capability $(\beta=0.246, p$ $=0.003)$ and network resource $(\beta=0.187, p=0.026)$ positively influenced profit growth. Similar result was found upon adding the moderator where marketing capability $(\beta$ $=0.605, p=0.014)$ and network resource $(\beta=0.623, p=$ 0.033 ) positively influenced profit growth. However, network resource did not moderate the relationship between marketing capability and profit growth $(\beta=-0.685, p=$ 0.118).

TABLE 1. Marketing capibilities results

\begin{tabular}{llllll}
\hline \hline & B & SE-B & $\beta$ & $\boldsymbol{t}$ & Sig. \\
\hline Model 1 & & & & & \\
MC & 0.356 & 0.120 & 0.246 & 2.967 & 0.003 \\
NR & 0.268 & 0.119 & 0.187 & 2.252 & 0.026 \\
Model 2 & & & & & \\
MC & 0.876 & 0.352 & 0.605 & 2.491 & 0.014 \\
NR & 0.892 & 0.415 & 0.623 & 2.151 & 0.033 \\
MC*NR & -0.191 & 0.121 & -0.685 & -1.571 & 0.118 \\
$R^{2}$ & $0.136 ; 0.149$ & & & & \\
\hline \hline
\end{tabular}

MC = Marketing Capability; NR = Network Resource

\section{Marketing Capability, Network Resource and Sales Growth}

Table 2 shows the result for the contribution of marketing capability and network resource towards sales growth satisfaction of Bumiputera online entrepreneurs. When there was no moderator, both marketing capability $(\beta=0.176, p$ $=0.039)$ and network resource $(\beta=0.190, p=0.026)$ pos- itively influenced sales growth. Similar result was found upon adding the moderator where marketing capability $(\beta$ $=0.500, p=0.046)$ and network resource $(\beta=0.584, p=$ $0.051)$ positively influenced sales growth. However, network resource did not moderate the relationship between marketing capability and sales growth $(\beta=-0.618, p=$ 0.168).

TABLE 2. Marketing capibilities results

\begin{tabular}{llllll}
\hline \hline & B & SE-B & $\beta$ & $\boldsymbol{t}$ & Sig. \\
\hline Model 1 & & & & & \\
MC & 0.263 & 0.127 & 0.176 & 2.078 & 0.039 \\
NR & 0.281 & 0.125 & 0.190 & 2.245 & 0.026 \\
Model 2 & & & & & \\
MC & 0.746 & 0.371 & 0.500 & 2.010 & 0.046 \\
NR & 0.862 & 0.438 & 0.584 & 1.969 & 0.051 \\
MC*NR & -0.178 & 0.128 & -0.618 & -1.384 & 0.168 \\
$R^{2}$ & $0.097 ; 0.108$ & & & & \\
\hline \hline
\end{tabular}

$\mathrm{MC}=$ Marketing Capability; NR = Network Resource 
Marketing Capability, Network Resource and Number of New customers Growth

Table 3 shows the result for the contribution of marketing capability and network resource towards new customers growth satisfaction of Bumiputera online entrepreneurs. Surprisingly, marketing capability did not influence the growth of new customers significantly neither directly, nor when moderator came in play. Network resource positively and directly influenced new customers growth when there was no moderator $(\beta=0.291, p=0.001)$. Similar result - but at $10 \%$ significant level - was found upon adding the moderator $(\beta=0.515, p=0.084)$. However, network resource did not moderate the relationship between marketing capability and new customers growth $(\beta=-0.352, p=0.431)$.

TABLE 3. Marketing capibilities results

\begin{tabular}{llllll}
\hline \hline & B & SE-B & $\beta$ & $t$ & Sig. \\
\hline Model 1 & & & & & \\
MC & 0.099 & 0.120 & 0.069 & 0.824 & 0.411 \\
NR & 0.409 & 0.118 & 0.291 & 3.454 & 0.001 \\
Model 2 & & & & & \\
MC & 0.360 & 0.353 & 0.254 & 1.022 & 0.309 \\
NR & 0.723 & 0.416 & 0.515 & 1.740 & 0.084 \\
MC*NR & -0.096 & 0.122 & -0.352 & -0.789 & 0.431 \\
$R^{2}$ & $0.107 ; 0.111$ & & & & \\
\hline \hline
\end{tabular}

MC = Marketing Capability; NR = Network Resource

\section{Marketing Capability, Network Resource and Number of Repeat Customer Growth}

Table 4 shows the result for the contribution of marketing capability and network resource towards number of repeat customer growth satisfaction of Bumiputera online entrepreneurs. When there was no moderator, both marketing capability $(\beta=0.213, p=0.011)$ and network resource ( $\beta=0.219, p=0.009$ ) positively influenced the performance growth. Similar result was found upon adding the moderator where marketing capability $(\beta=0.468, p=0.057)$ and network resource $(\beta=0.530, p=0.071)$ positively influenced number of repeat customer growth albeit at $10 \%$ significance level. However, network resource did not moderate the relationship between marketing capability and number of repeat customer growth $(\beta=-0.488, p=0.267)$.

TABLE 4. Marketing capibilities results

\begin{tabular}{llllll}
\hline \hline \multicolumn{1}{c}{ B } & SE-B & $\beta$ & $\boldsymbol{t}$ & Sig. \\
\hline Model 1 & & & & & \\
MC & 0.315 & 0.123 & 0.213 & 2.561 & 0.011 \\
NR & 0.321 & 0.122 & 0.219 & 2.637 & 0.009 \\
Model 2 & & & & & \\
MC & 0.693 & 0.361 & 0.468 & 1.918 & 0.057 \\
NR & 0.775 & 0.426 & 0.530 & 1.820 & 0.071 \\
MC*NR & -0.139 & 0.125 & -0.488 & -1.113 & 0.267 \\
$R^{2}$ & $0.134 ; 0.141$ & & & & \\
\hline \hline
\end{tabular}

MC = Marketing Capability; NR = Network Resource

\section{Marketing Capability, Network Resource and Overall Performance Growth}

Table 5 shows the result for the contribution of marketing capability and network resource towards overall performance growth satisfaction of Bumiputera online entrepreneurs. When there was no moderator, both marketing capability $(\beta=0.224, p=0.006)$ and network resource
( $\beta=0.281, p=0.001$ ) positively influenced the overall performance. Similar result was found upon adding the moderator where marketing capability $(\beta=0.581, p=0.015)$ and network resource $(\beta=0.714, p=0.012)$ positively influenced overall performance. However, network resource did not moderate the relationship between marketing capability and overall performance growth $(\beta=-0.681, p=0.110)$. 
TABLE 5. Marketing capibilities results

\begin{tabular}{llllll}
\hline \hline & B & SE-B & $\beta$ & $t$ & Sig. \\
\hline Model 1 & & & & & \\
MC & 0.258 & 0.093 & 0.224 & 2.783 & 0.006 \\
NR & 0.320 & 0.092 & 0.281 & 3.483 & 0.001 \\
Model 2 & & & & & \\
MC & 0.669 & 0.272 & 0.581 & 2.463 & 0.015 \\
NR & 0.813 & 0.320 & 0.714 & 2.540 & 0.012 \\
MC*NR & -0.151 & 0.094 & -0.681 & -1.608 & 0.110 \\
$R^{2}$ & $0.184 ; 0.198$ & & & & \\
\hline \hline
\end{tabular}

MC = Marketing Capability; NR = Network Resource

\section{DISCUSSION}

The research aimed to identify the contribution of marketing capability and network resource towards the performance satisfaction of Bumiputera online entrepreneurs in Malaysia.

Model 1: It was found that when network resource was not treated as the moderator, both marketing capability and network resource had a significant and positive relationship with all performance measurement that were profit growth, sales growth, number of new customers growth, number of repeat customer growth, and overall performance. Hence, the study concurred with past studies that found the direct influence of marketing capability e.g., (Azizi et al., 2009; Krasnikov \& Jayachandran, 2008; Vorhies et al., 1999), and network resource e.g., (Ainuddin et al., 2007; Chen et al., 2007; Jones \& Jayawarna, 2010; Lechner \& Dowling, 2003; Madsen, 2007) on the business performance.

Model 2: Analyses showed that when network resource was entered as the moderator, marketing capability still proved to be a very valuable capability because it affected directly the profit growth, sales growth, number of repeat customer growth, and overall growth performance. In other words, Bumiputera online entrepreneurs of Malaysia need the capability to offer suitable and quality products and services, acceptable price, effective promotion, and effective distribution in order to gain performance satisfaction. Thus, H1 is accepted. Similarly, accepting $10 \%$ significant level, network resource contribute directly and significantly to profit growth, sales growth, number of new customers, number of repeat customer growth, and overall growth performance. This showed that resources gain through network including information, help, business opportunities, and other resources, would lead to satisfaction in performance. Thus, $\mathrm{H} 2$ is accepted.

However, network resource did not moderate the relationship between marketing capability and performance, hence the rejection of H3. The finding was consistent with the study by Vissa and Chacar (2006). The reason may be because there was a gap in term of age of respondents, where the youngest was 14 while the oldest was 53 years old. This could lead to different characteristics of network composition, which could in turn affect the findings. In fact, analyses showed that upon adding network resource as moderating could make the relationship between marketing capability and performance negative, as if network resource had a damaging power. Fortunately the results were not significant.

Analysis further revealed that in order to be satisfied with the growth in the number of new customers, Bumiputera online entrepreneurs should rely on the network instead of marketing capability. This may be because the connections with potential new customers cannot be built through marketing, but need the help of friends, family, current customers, and acquaintances. In addition, only network could provide the opportunities to acquire new customers; even though marketing capability would influence sales growth, this did not mean that the number of new customers would also grow.

\section{CONCLUSION \& IMPLICATIONS}

Findings revealed that Bumiputera online entrepreneurs in Malaysia need to strengthen their marketing capability and network resource as both of these factors could make them satisfied with their performance. Marketing capability would enable Bumiputera online entrepreneurs to offer quality and demanded products and services, put attractive but profitable price, effective promotion and efficient distribution. Network resource would help Bumiputera online entrepreneurs to get help if needed such as access to information, resources, and advices. Network resource however, was found not to have any moderating effect on the marketing capability-performance relationship.

The research is significant as this is one of the attempts to understand and identify the performance factors for Bumi- 
putera online entrepreneurs, with the hope to help these entrepreneurs can be successful. At the same time, this research also could aid the government aim to create Bumiputera's wealth and rectifying economic imbalance among communities, which have been a national agenda since the institution of NEP in 1970 (Ishak, 2014). The findings could also support entrepreneurship development pro- grams such as programs organized by MARA and MDEC. It is recommended for future research to strengthen the measurement for marketing capability and network resource of entrepreneurs, since most past studies focus on the organization's capabilities and resources. In addition, future research could also further investigate other roles of network resource.

\section{REFERENCES}

Adora, N. M. (2017). Entrepreneurial activities and teaching performance of faculty members of the University of Eastern Philippines. International Journal of Business and Administrative Studies, 3(4), 142-151. doi:https://doi.org/ 10.20469 /ijbas.3.10002-4

Ahuja, G. (2000). The duality of collaboration: Inducements and opportunities in the formation of interfirm linkages. Strategic Management Journal, 21(3), 317-343. doi:https://doi.org/10.1002/(sici)1097-0266(200003)21:3<317:: aid-smj90>3.0.co;2-b

Ainuddin, R. A., Beamish, P. W., Hulland, J. S., \& Rouse, M. J. (2007). Resource attributes and firm performance in international joint ventures. Journal of World Business, 42(1), 47-60. doi:https://doi.org/10.1016/j.jwb.2006.11.001

Alshehhi, A. S. (2016). Organizational knowledge systems. International Journal of Business and Administrative Studies, 2(6), 193-200. doi:https://doi.org/10.20469/ijbas.2.10004-6

Anggadwita, . D. W., G. (2016). Women's entrepreneurial intentions in Micro and Small Enterprises (MSEs) in Indonesia: The influence of environmental factors on perceived behavioral control. Journal of Administrative and Business Studies, 1(1), 1-7. doi:https://doi.org/10.20474/jabs-1.1.1

Anwar, M. N., \& Daniel, E. (2016). Entrepreneurial marketing in online businesses: The case of ethnic minority entrepreneurs in the UK. Qualitative Market Research: An International Journal, 19(3), 310-338. doi:https://doi.org/10.1108/qmr -04-2015-0029

AT Kearney. (n.d). National ecommerce strategic roadmap overview. Retrieved from https://goo.gl/dBveqb (accessed on 13 May, 2018)

Azizi, S., Movahed, S. A., \& Khah, M. H. (2009). The effect of marketing strategy and marketing capability on business performance: Case study Iran's medical equipment sector. Journal of Medical Marketing, 9(4), 309-317. doi:https:// doi.org/10.1057/jmm.2009.33

Azlina, A. J. (2016). How i became an online freelancer. Selangor, Malaysia: MPH Group Publishing Sdn Bhd.

Barney, J. (1991). Firm resources and sustained competitive advantage. Journal of Management, 17(1), 99-120. doi:https:// doi.org/10.1177/014920639101700108

Barney, J. B. (1995). Looking inside for competitive advantage. Academy of Management Perspectives, 9(4), 49-61. doi: https://doi.org/10.5465/ame.1995.9512032192

Bernama. (2017). 50,882 online entrepreneurs register with CCM. Retrieved from https://goo.gl/CaE6Vp (accessed on 21 May, 2018)

Bizon, W. (2016). Stimulating entrepreneurship by introducing behavioural incentives, propensity to use financial instruments in the context of decision makers' personal characteristics and their financial knowledge in Polish SMEs. Journal of Administrative and Business Studies, 2(6), 270-279. doi:https://doi.org/10.20474/jabs-2.6.2

Borch, O. J., Huse, M., \& Senneseth, K. (1999). Resource configuration, competitive strategies, and corporate entrepreneurship: An empirical examination of small firms. Entrepreneurship Theory and Practice, 24(1), 49-70. doi:https:// doi.org/10.1177/104225879902400104

Burt, R. S. (2000). The network structure of social capital. Research in Organizational Behavior, 22, 345-423. doi:https:// doi.org/10.1016/s0191-3085(00)22009-1

Chang, T.-l. (1996). Cultivating global experience curve advantage on technology and marketing capabilities. International Marketing Review, 13(6), 22-42. doi:https://doi.org/10.1108/02651339610151908 
Chen, C. N., Tzeng, L. C., Ou, W. M., \& Chang, K. T. (2007). The relationship among social capital, entrepreneurial orientation, organizational resources and entrepreneurial performance for new ventures. Contemporary Management Research, 3(3), 45-70. doi:https://doi.org/10.7903/cmr.90

Day, G. S. (1994). The capabilities of market-driven organizations. The Journal of Marketing, 58(4), 37-52. doi:https:// doi.org/10.2307/1251915

Department of Statistics. (2017). Current population estimates, Malaysia, 2016-2017. Retrieved from https://goo.gl/ D8X3Qu (accessed on 2 July, 2018)

Di Domenico, M., Daniel, E., \& Nunan, D. (2014). Mental mobility'in the digital age: Entrepreneurs and the online home-based business. New Technology, Work and Employment, 29(3), 266-281. doi:https://doi.org/10.1111/ntwe.12034

Dierickx, I., \& Cool, K. (1989). Asset stock accumulation and sustainability of competitive advantage. Management Science, 35(12), 1504-1511. doi:https://doi.org/10.1287/mnsc.35.12.1504

Ee, A. N. (2017). Malaysians are online shopaholics. Retrieved from https://goo.gl/1MHQVm (accessed on 23 May, 2018)

Eyal, O. (2008). Caught in the net: The network-entrepreneurship connection in public schools. International Journal of Educational Management, 22(5), 386-398. doi:https://doi.org/10.1108/09513540810883131

Eze, I. O. (2017). Corporate governance mechanisms and earnings management in Nigerian food product companies. Journal of Administrative and Business Studies, 3(1), 1-9. doi:https://doi.org/10.20474/jabs-3.1.1

Foss, N. J., et al. (1999). Networks, capabilities, and competitive advantage. Scandinavian Journal of Management, 15(1), 1-16. doi:https://doi.org/10.1016/s0956-5221(98)00030-x

Granovetter, M. (1983). The strength of weak ties: A network theory revisited. In R. Collins (Ed.), Sociological theory. San Francisco, CA: Jossey-Bass.

Gulati, R., Nohria, N., \& Zaheer, A. (2000). Strategic networks. Strategic Management Journal, 21(3), 203-215. doi:https:// doi.org/10.1002/(sici)1097-0266(200003)21:3<203::aid-smj102>3.0.co;2-k

Irfan, K. (2013). Rahsia jutawan-jutawan internet terbongkar. Peachtree Road, GA: True Wealth Sdn Bhd.

Ishak, M. M. (2014). The politics of bangsa Malaysia: Nation-building in a multiethnic society. Changlun, Malaysia: Universiti Utara Malaysia Press.

Jones, O., \& Jayawarna, D. (2010). Resourcing new businesses: Social networks, bootstrapping and firm performance. Venture Capital, 12(2), 127-152. doi:https://doi.org/10.1080/13691061003658886

Kali, R. (1999). Endogenous business networks. Journal of Law, Economics, and Organization, 15(3), 615-636. doi:https:// doi.org/10.1093/jleo/15.3.615

Krasnikov, A., \& Jayachandran, S. (2008). The relative impact of marketing, research-and-development, and operations capabilities on firm performance. Journal of Marketing, 72(4), 1-11. doi:https://doi.org/10.1509/jmkg.72.4.1

Krisnawati, N., Perangin-Angin, L. K., Zainal, M., \& Suardi, I. (2016). Brand equity analysis and its impact on the loyal customer of local batik to develop its competitiveness (An empirical study of batik Banten in south Tangerang). Journal of Administrative and Business Studies, 2(4), 189-207. doi:https://doi.org/10.20474/jabs-2.4.5

Kuo, M. P., \& Chen, Y. M. (2015). A study on the relationships among body sensory experience, customer satisfaction and customer loyalty-beauty SPA center as an example. International Journal of Business and Administrative Studies, 1(2), 61-67. doi:https://doi.org/10.20469/ijbas.10003-2

Lechner, C., \& Dowling, M. (2003). Firm networks: External relationships as sources for the growth and competitiveness of entrepreneurial firms. Entrepreneurship \& Regional Development, 15(1), 1--26. doi:https://doi.org/10.1080/ 08985620210159220

Madsen, E. L. (2007). The significance of sustained entrepreneurial orientation on performance of firms: A longitudinal analysis. Entrepreneurship and Regional Development, 19(2), 185-204. doi:https://doi.org/10.1080/ 08985620601136812

Miliza, G. (2016). Buat duit dengan facebook dan instagram. Jakarta, Indonesia: PTS Publishing House.

Möller, K., \& Anttila, M. (1987). Marketing capability: A key success factor in small business? Journal of Marketing Management, 3(2), 185-203. doi:https://doi.org/10.1080/0267257x.1987.9964038

Nor Liza, A. B. (2016). Buat duit dengan dropship: Panduan menjana pendapatan dengan dropship. Selangor, Malayisa: PTS Publishing House. 
O’Donnell, A., Gilmore, A., Cummins, D., \& Carson, D. (2001). The network construct in entrepreneurship research: A review and critique. Management Decision, 39(9), 749-760. doi:https://doi.org/10.1108/eum0000000006220

Oetomo, H. W., \& Budiyanto. (2017). Brand image as mediation effect of experiential marketing and differentiation product to the buying decision of Toyota cars. International Journal of Business and Administrative Studies, 3(5), $175-182$. doi:https://doi.org/10.20469/ijbas.3.10003-5

Paquette, H. (2013). Social media as a marketing tool: A literature review (Unpublished master's thesis). University of Rohde Island, South Kingstown, Rhode Island.

Porter, M. E., \& ilustraciones Gibbs, M. (2001). Strategy and the internet. Harvard Business Review, 5(7), 63-78.

Ripain, N., Amirul, S. M., \& Mail, R. (2017). Financial literacy and SMEs' potential entrepreneurs: The case of Malaysia. Journal of Administrative and Business Studies, 3(2), 60-68. doi:https://doi.org/10.20474/jabs-3.2.1

Rouse, M. J., \& Daellenbach, U. S. (1999). Rethinking research methods for the resource based perspective: Isolating sources of sustainable competitive advantage. Strategic Management Journal, 20(5), 487-494. doi:https://doi.org/10.1002/ (sici)1097-0266(199905)20:5<487::aid-smj26>3.0.c0;2-k

Shin, S. J., \& Seo, W. (2017). Identifying new technology areas based on firm's internal capabilities. Journal of Administrative and Business Studies, 3(3), 114-121. doi:https://doi.org/10.20474/jabs-3.3.1

Smith, D. A., \& Lohrke, F. T. (2008). Entrepreneurial network development: Trusting in the process. Journal of Business Research, 61(4), 315-322. doi:https://doi.org/10.1016/j.jbusres.2007.06.018

Srivastava, R. K., Fahey, L., \& Christensen, H. K. (2001). The resource-based view and marketing: The role of market-based assets in gaining competitive advantage. Journal of Management, 27(6), 777-802. doi:https://doi.org/10.1016/s0149 -2063(01)00123-4

Tsai, M.-T., \& Shih, C.-M. (2004). The impact of marketing knowledge among managers on marketing capabilities and business performance. International Journal of Management, 21(4), 524-530.

Vertel, A. (2012). Self-efficacy and entrepreneurship: A generic qualitative study of the self-perceived attitudes and behaviors of successful online women entrepreneurs (Unpublished doctoral dissertation). Capella University, Minneapolis, Minnesota.

Vissa, B., \& Chacar, A. S. (2006). External networks of entrepreneurial teams and high technology venture performance in emerging markets. In Cooper, S. Alvarez, A. Carrera, L. Mesquita \& R. Vassolo (Eds.), Entrepreneurial strategi: New technologies in emerging markets. Hobbken, NJ: Blackwell Publishing.

Vorhies, D. W., Harker, M., \& Rao, C. (1999). The capabilities and performance advantages of market-driven firms. European Journal of Marketing, 33(11/12), 1171-1202. doi:https://doi.org/10.1177/031289620002500203

Weerawardena, J. (2003). The role of marketing capability in innovation-based competitive strategy. Journal of Strategic Marketing, 11(1), 15-35. doi:https://doi.org/10.1080/0965254032000096766

Wen, H. J., Chen, H. G., \& Hwang, H. G. (2001). E-commerce web site design: Strategies and models. Information Management and Computer Security, 9(1), 5-12. doi:https://doi.org/10.1108/09685220110366713

Wright, P. M., McMahan, G. C., \& McWilliams, A. (1994). Human resources and sustained competitive advantage: A resourcebased perspective. International Journal of Human Resource Management, 5(2), 301-326. doi:https://doi.org/ 10.1080/09585199400000020

Yang, K.-S., \& Lin, C.-Y. (2012). Network dynamics and innovative performance: The moderating effects of network resources. African Journal of Business Management, 6(4), 1545-1552. doi:https://doi.org/10.5897/ajbm11.2350 